\title{
PROTECTIVE EFFECT OF KADUKKAI MAATHIRAI (TERMINALIA CHEBULA-BASED POLYHERBAL SIDDHA FORMULATION) IN ETHANOL-INDUCED LIVER DISEASE IN RATS
}

\author{
MANJUNATH SHETTY ${ }^{1}$, SMITA SHENOY ${ }^{2 *}$, VASUDHA DEVI ${ }^{1}$, NITESH KUMAR ${ }^{3}$, ARUL AMUTHAN ${ }^{1}$, \\ GANESH SHENOY $\mathrm{K}^{1}$, PAVITHRA ${ }^{4}$
}

\begin{abstract}
${ }^{1}$ Department of Pharmacology, Melaka Manipal Medical College, Manipal Academy of Higher Education, Manipal, Karnataka, India. ${ }^{2}$ Department of Pharmacology, Kasturba Medical College, Manipal, Manipal Academy of Higher Education, Manipal, Karnataka, India. ${ }^{3}$ Department of Pharmacology, Manipal College of Pharmaceutical Sciences, Manipal Academy of Higher Education, Manipal, Karnataka, India. ${ }^{4}$ Department of Pathology, Melaka Manipal Medical College, Manipal Academy of Higher Education, Manipal, Karnataka, India. Email: smita.shenoy@manipal.edu
\end{abstract}

Received: 18 April 2018, Revised and Accepted: 23 July 2018

ABSTRACT

Objective: The objective of this study was to evaluate the prophylactic effect of Kadukkai maathirai (KM) against ethanol-induced hepatotoxicity in rats.

Methods: Four groups $(\mathrm{n}=6)$ of adult female Sprague-Dawley rats were used. Ethanol was administered in the dose of $45 \% \mathrm{v} / \mathrm{v} 15 \mathrm{~mL} / \mathrm{kg} / \mathrm{body}$ weight twice a day for 8 weeks in the study. The four groups were treated orally for 8 weeks with $2 \%$ gum acacia (control), ethanol (toxic control), ethanol $+\mathrm{KM} 72 \mathrm{mg} / \mathrm{kg}$, and ethanol $+\mathrm{KM} 400 \mathrm{mg} / \mathrm{kg}$, respectively. At the end of 8 weeks, blood was collected by a retro-orbital puncture for the estimation of liver enzymes (aspartate aminotransferase [AST] and alanine aminotransferase [ALT]). The liver was dissected out for histopathology. Using one-way ANOVA and post hoc Tukey's test, the data were analyzed.

Results: There was a significant $(\mathrm{p}<0.05)$ decrease in the serum AST and ALT level in rats treated with $\mathrm{KM} 72 \mathrm{mg} / \mathrm{kg}$ as compared to toxic control. Liver parenchyma showed near normal architecture in $\mathrm{KM} 72 \mathrm{mg} / \mathrm{kg}$-treated group as compared to ethanol-treated group which showed extensive ballooning degeneration of hepatocytes and microvesicular steatosis.

Conclusion: KM, in the dose of $72 \mathrm{mg} / \mathrm{kg}$, which is the therapeutic dosage described in Siddha additional literature, exerted hepatoprotective effect against ethanol-induced liver damage in rats.

Keywords: Kadukkai maathirai, Hepatoprotective effect, Microvesicular steatosis, Liver enzymes, Siddha.

(C) 2018 The Authors. Published by Innovare Academic Sciences Pvt Ltd. This is an open access article under the CC BY license (http://creativecommons. org/licenses/by/4. 0/) DOI: http://dx.doi.org/10.22159/ajpcr.2018.v11i11.26773

\section{INTRODUCTION}

Chronic liver disease remains a major health problem globally, affecting more than $10 \%$ of the population [1]. Worldwide, viral hepatitis, alcohol, and non-alcoholic fatty liver disease are the common causative factors of liver dysfunction [2-4]. They are also considered to be risk factors for hepatocellular carcinoma (HCC) [5]. The common cause of death in these patients is cardiovascular events, but they also have an increased liver-related mortality rate predominantly when cirrhosis and HCC develop [6,7]. Alcoholic liver disease (ALD) ranges from steatosis to frank cirrhosis. More than one stage of the disease might be present simultaneously in a patient with ALD $[8,9]$. A person with chronic ethanol intake will end up with liver damage by a process which involves cytokines, oxidative and nitrosative stress, hypoxia, and alterations in energy metabolism [10-12]. Asceticism is an important treatment measure for patients with ALD but difficult to sustain. Agents such as naltrexone and acamprosate have been used to maintain asceticism, but they did not show any major impact on alcoholics who were not detoxified or became ascetic $[13,14]$.

Steroids and anticytokines have been used but are associated with adverse effects [15]. Treatment of most of the liver disorders including ALD largely involves removal of toxins, use of phytochemical agents, and other supportive agents for the regeneration of the liver. Drugs obtained from plants, namely silymarin, phyllanthin, lecithin, catechin, glycyrrhizin, picroside, baicalein, anddaphnoretin, are used for the regeneration of the liver [16].
There are various studies which have demonstrated excellent hepatoprotective effects of different herbs used in traditional Indian medicine $[17,18]$. Siddha is one of the earliest systems of medicine practiced in India, Sri Lanka, and Malaysia [19]. Kadukkai maathirai (KM) is a polyherbal Siddha preparation described in the traditional Siddha literature wherein it is indicated for anemia, sobai (generalized edema due to liver disease), and mahodharam (ascites due to liver disease) by Siddha doctors $[20,21]$.

KM is composed of Terminalia chebula, Piper nigrum, Eclipta alba, Citrus limon, and ferrous sulfate (processed by traditional method) [21]. Each plant in this formulation has individually demonstrated the hepatoprotective effect in rats in the previous studies. T. chebula (fruit) has been shown to prevent isoniazid, rifampicin, and pyrazinamideinduced liver toxicity [22]. P. nigrum has shown a hepatoprotective effect in carbon tetrachloride as well as thioacetamide-induced liver damage in rats $[23,24]$. Ethanolic extract of $C$. limon produced a reduction in the elevated liver enzymes in carbon tetrachloride $\left(\mathrm{CCl}_{4}\right)$-induced liver toxicity in rats [25]. E. alba produced a significant restoration of microsomal enzymes, aminopyrine $\mathrm{N}$-demethylase, glucose 6-phosphatase, ALP, and lysosomal acid phosphatase in $\mathrm{CCl}_{4}{ }^{-}$ induced hepatotoxicity in rats [26,27]. Studies with KM have shown its hepatoprotective effect in $\mathrm{CCl}_{4}$-induced hepatic damage in rats [21].

The current experiment was undertaken to investigate the hepatoprotective outcome of KM treatment in rats with alcoholinduced toxicity. 


\section{MATERIALS AND METHODS}

\section{Drug}

KM was procured from SKM Siddha and Ayurveda Ltd., Erode, Tamil Nadu, India.

\section{Animals}

Hepatoprotective effects of KM were evaluated using adult female SpragueDawley rats (weighing 150-200 g). Female Wistar rats (weighing 150$200 \mathrm{~g}$ ) were used for acute toxicity study. They were kept individually in polypropylene cages and maintained at a temperature of $27 \pm 3^{\circ} \mathrm{C}$, relative humidity of $60 \pm 10 \%$, and $12 \mathrm{~h}$ light/dark cycle. The experiments were conducted according to the ethical norms laid down by the Committee for the Purpose of Control and Supervision on Experimentations on Animals guidelines after approval of the experimental protocol by the Institutional Animal Ethics Committee, Manipal.

\section{Acute toxicity study}

The OECD 423 guideline (acute toxic class method) was followed for the experiment. KM was dissolved in normal saline and was administered through oral gavage to female Wistar rats $(n=3)$ in a dose of $5 \mathrm{mg} / \mathrm{kg}$ body weight. The rats were observed for first $24 \mathrm{~h}$ for any signs and symptoms of toxicity or death and later for 2 weeks. As no toxic symptoms were observed in all three animals, the dose of $\mathrm{KM}$ was escalated to $50 \mathrm{mg} / \mathrm{kg}$ body weight in additional three rats. The procedure was repeated with higher doses of KM - $300 \mathrm{mg} / \mathrm{kg}$, $2000 \mathrm{mg} / \mathrm{kg}$, and $4000 \mathrm{mg} / \mathrm{kg}$ body weight using three rats for each dose. There were no toxic symptoms observed even at the highest dose.

\section{Hepatoprotective activity}

Two doses of KM were selected for evaluation of its hepatoprotective effect. One of the doses selected was based on the human dose of KM. As the human dose of KM is $200 \mathrm{mg}$ twice a day, the human equivalent dose for rat, i.e., $36 \mathrm{mg} / \mathrm{kg}$ body weight was derived based on body surface area. The other dose selected was $400 \mathrm{mg} / \mathrm{kg}$ body weight which is onetenth of the maximum tolerated dose $(4000 \mathrm{mg} / \mathrm{kg}$ body weight based on acute toxicity study).

Four groups with six rats in each (a total of 24 rats) were used. All groups received respective drugs for 8 weeks. Group 1 (control) received 2\% gum acacia $1 \mathrm{~mL} / \mathrm{kg}$ orally. Hepatotoxicity was induced in other rats (Groups 2-4) by administering ethanol orally $45 \% \mathrm{v} / \mathrm{v} 15 \mathrm{~mL} / \mathrm{kg}$ body weight twice a day for 8 weeks. Group 2 (toxic control) received ethanol. Groups 3 and 4 were treated with $\mathrm{KM}-72 \mathrm{mg} / \mathrm{kg}$ and $400 \mathrm{mg} / \mathrm{kg}$, respectively, along with ethanol for 8 weeks. After 8 weeks of treatment, blood was collected by retro-orbital puncture. Biochemical estimation of liver enzymes such as aspartate transaminase (AST) and alanine transaminase (ALT) was done using standard biochemical kits [28].

Rat liver was collected and fixed in $10 \%$ formaldehyde solution for microscopic examination using hematoxylin-eosin stain.

\section{Statistics}

Statistical program SPSS 16.0 was used. Data were expressed in terms of mean and standard deviation. One-way ANOVA followed by post hoc Tukey's test was used. A p $<0.05$ was considered statistically significant.

\section{RESULTS}

Biochemical estimation in serum

Chronic administration of ethanol showed a significant $(\mathrm{p}<0.05)$ rise in serum AST and ALT levels as compared to normal control. Treatment with $\mathrm{KM}$ at $72 \mathrm{mg} / \mathrm{kg}$ significantly $(\mathrm{p}<0.05)$ prevented the ethanolinduced rise in AST and ALT levels when compared to the rats who were administered ethanol only (Table 1 ). Higher dose (400 mg/kg) of KM did not have any beneficial effect in ethanol-induced hepatotoxicity.

\section{Histopathology}

Chronic oral administration of ethanol to rats caused enlargement of the liver. Histopathology of liver of normal rats showed liver parenchyma with normal architecture (Fig. 1a). There was extensive ballooning degeneration of hepatocytes and microvesicular steatosis in ethanol only treated group (Fig. 1b). Section of liver parenchyma of rats treated with KM $72 \mathrm{mg} / \mathrm{kg}$ along with ethanol showed near normal architecture (Fig. 1c). Focal areas of apoptosis and giant mitochondria in hepatocytes were evident in rats treated with $400 \mathrm{mg} / \mathrm{kg}$ of KM (Fig. 1d).

\section{DISCUSSION}

In the present study, the effect of KM on ethanol-induced liver injury was evaluated. Alcohol is a major cause of hepatic dysfunction characterized by fatty liver, hepatitis, and cirrhosis [29]. It produces a dose-related damage in the liver [30]. Reactive oxygen species play an important role in the ethanol-induced hepatic damage. They damage hepatocyte membrane, DNA, mitochondria, and other cellular components. In addition, cytokines released from activated Kupffer cells cause necrosis of hepatocytes followed by fibrosis [31-35]. In this study, treatment with ethanol caused an elevation of hepatic enzymes such as ALT and AST which indicates hepatocyte membrane disruption and mitochondrial damage, respectively [36].

$\mathrm{KM}$, in a lower dose, prevented ethanol-induced hepatotoxicity as was evident from the biochemical and histopathological changes. KM consists of herbs such as T. chebula, P. nigrum, E. alba, and C. limon [21]. C. limon has antioxidants such as Vitamin $C$ and flavonoids which target the free radicals [37]. P. nigrum exerts antioxidant effect which could be mediated by flavonoids and phenolic constituents. It has been shown to inhibit lipid peroxidation and generation of superoxide free radicals [38,39]. Gallic acid and chebulic acid are important constituents of T. chebula. Gallic acid has antioxidant and anti-inflammatory properties. Chebulic acid is known to be an antioxidant and hepatoprotective agent. It has produced immunemodulation effects on IL-6 and IL-10 in collagen-induced arthritis model [40-44]. Coumestans, present in E. alba, have been shown to exert a protective effect in liver disorders and stimulate liver cell regeneration [45]. In an earlier study, a 28-day treatment with KM (36
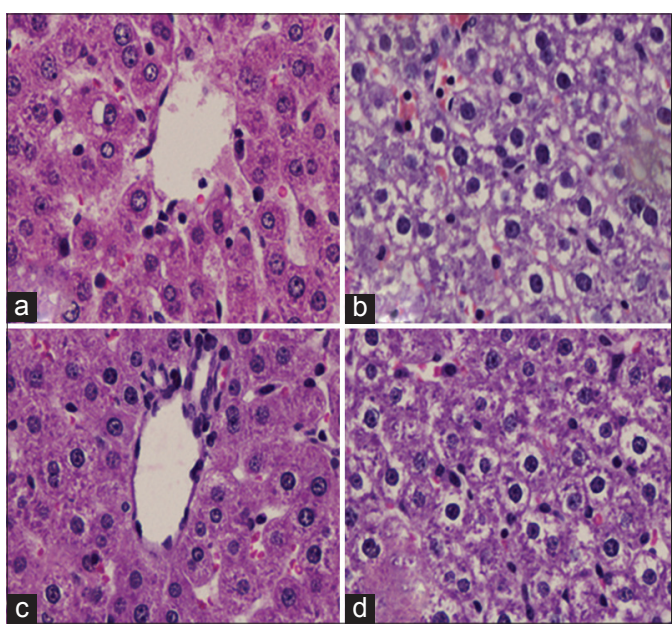

Fig. 1: Histopathology of the liver. (a) Normal rats (b) ethanoltreated group (c) ethanol + Kadukkai maathirai 72 mg/kg-treated group. (d) Ethanol + Kadukkai maathirai 400 mg/kg-treated group

Table 1: Effect of $K$. maathirai on liver enzyme levels in ethanol-induced liver damage in prague-dawley rats

\begin{tabular}{lll}
\hline Group & AST, IU/L & ALT, IU/L \\
\hline Group 1, vehicle control & $49 \pm 6.9$ & $25 \pm 2.9$ \\
Group 2, ethanol control & $126 \pm 7.3^{*}$ & $57 \pm 2.4^{*}$ \\
Group 3, ethanol+KM 72 mg/kg & $64 \pm 5.9^{* *}$ & $32 \pm 3.7^{* *}$ \\
Group 4, ethanol+KM 400 mg/kg & $113 \pm 16.2$ & $52 \pm 13.6$ \\
\hline
\end{tabular}

Values are expressed in mean \pm SD, KM: Kadukkai maathirai, ${ }^{*} \mathrm{p}<0.05$ vs. control group, ${ }^{* *} \mathrm{p}<0.05$ versus ethanol group, SD: Standard deviation 
and $72 \mathrm{mg} / \mathrm{kg}$ ) showed a protective effect against carbon tetrachlorideinduced hepatotoxicity in rats [19].

Therefore, we hypothesize that the hepatoprotective activity shown by a low dose of KM could be due to the presence of active phytoconstituents in it. As KM is a herbomineral formulation, further analysis needs to be done to find the reason for the variation in response at different doses.

\section{CONCLUSION}

Overall, the result of the present study indicates that KM demonstrated a significant hepatoprotective activity against ethanol-induced hepatotoxicity in rats

\section{ACKNOWLEDGMENT}

The authors thank SKM Siddha and Ayurveda Ltd, Erode, Tamil Nadu, India, for providing a free sample of KM.

\section{AUTHORS' CONTRIBUTION}

Manjunath Shetty - planned the study design and conducted the study and wrote the manuscript and statistical analysis. Smita Shenoy - guide for the project, planned the study design, and conducted it, wrote manuscript, interpretation of results. Vasudha Devi - conducted the study, statistical analysis, and review of manuscript. Nitesh Kumar - planned the study design and conducted study, wrote the manuscript, interpretation of results. Arul Amuthan - procurement of KM, conduction of the study, and interpretation of results. Ganesh Shenoy - conducted the study and wrote the manuscript. Pavithra P - conducted the study, histopathology, and wrote the manuscript.

\section{CONFLICTS OF INTEREST}

All authors have none to declare.

\section{REFERENCES}

1. Wood NJ. Liver: Nonobese individuals in the developing world are at risk of nonalcoholic fatty liver and liver disease. Nat Rev Gastroenterol Hepatol 2010;7:357.

2. Lazerow SK, Abdi MS, Lewis JH. Drug-induced liver disease 2004. Curr Opin Gastroenterol 2005;21;283-92

3. Baig NA, Herrine SK, Rubin R. Liver disease and diabetes mellitus. Clin Lab Med 2001;21:193-207.

4. Orman ES, Odena G, Bataller R. Alcoholic liver disease: Pathogenesis, management, and novel targets for therapy. J Gastroenterol Hepatol 2013;28:77-84.

5. Farazi PA, DePinho RA. Hepatocellular carcinoma pathogenesis: From genes toenvironment. Nat Rev Cancer 2006;6:674-87.

6. Soderberg C, Stål P, Askling J, Glaumann H, Lindberg G, Marmur J, et al. Decreased survival of subjects with elevated liver function tests during a 28-year follow-up. Hepatology 2010;51:595-602

7. Yatsuji S, Hashimoto E, Tobari M, Taniai M, Tokushige K, Shiratori K. Clinical features and outcomes of cirrhosis due to non-alcoholic steato hepatitis compared with cirrhosis caused by chronic hepatitis C. J Gastroenterol Hepatol 2009;24:248-54

8. Lefkowitch JH. Morphology of alcoholic liver disease. Clin Liver Dis 2005;9:37-53

9. Mendez-Sanchez N, Meda-Valdes P, Uribe M. Alcoholic liver disease. An update. Ann Hepatol 2005;4:32-42.

10. Arteel GE. Oxidants and antioxidants in alcohol-induced liver disease. Gastroenterology 2003;124:778-90.

11. Cunningham CC, Bailey SM. Ethanol consumption and liver mitochondria function. Biol Signals Recept 2001;10:271-82.

12. Hoek JB, Pastorino JG. Ethanol, oxidative stress, and cytokine-induced liver cell injury. Alcohol 2002;27:63-8.

13. Reynolds TB, Benhamou JP, Blake J, Naccarato R, Orrego H. Treatment of alcoholic hepatitis. Gastroenterol Int 1989;2:208-16.

14. Imperiale TF, McCullough AJ. Do corticosteroids reduce mortality from alcoholic hepatitis? A meta-analysis of the randomized trials. Ann Intern Med 1990;113:299-307.

15. O'Shea RS, Darasathy S, McCullough AJ. AASLD practice guidelines. Alcoholic liver disease. Hepatology 2010;51:307-28.

16. Negi AS, Kumar J, Luqman S, Shanker K, Gupta M, Khanuja S. Recent advances in plant hepatoprotectives: A chemical and biological profile of some important leads. Med Res Rev 2008;28:746-72.

17. Amir M, Mallick M, Ahmad N, Ali A, Ahmad S, Akhtar M, et al. Hepatoprotective effects of Punica granatum fruit against d-galactosamine induced hepatotoxicity in rats: In vitro and in vivo studies. Int J Pharm Pharm Sci 2017;9:168-72.

18. Salama R, Mohamed M, AbdElwahab M, Shakweer M. Assessment effect of Aloe vera, Azadirachta indica and Moringa oleifera aqueous extracts on carbon tetrachloride-induced hepatotoxicity in rats. Int J Pharm Pharm Sci 2016:8:83-9.

19. Velayudam, Amuthan A, Ilavarasan. Hepatoprotective activity of Kadukkai Maathirai (A siddha polyherbal formulation) against carbon tetrachloride induced liver damage in rat. Res J Pharm Sci 2012;1:17-21.

20. SKM Siddha and Ayurveda Company. Therapeutic Index Siddha (Hospital Pharmacopoeia). $1^{\text {st }}$ ed. India: SKM Siddha and Ayurveda Company; 2010. p. 166-7.

21. Velayudam, Ilavarasan, Amuthan A. Physico-chemical evaluation of kadukkai maathirai and its tablet formulation, a siddha iron preparation used in anemia. Int J Pharmacol Clin Sci 2012;1:3-8.

22. Tasduq SA, Singh K, Satti NK, Gupta DK, Suri KA. Terminalia chebula (fruit) prevents liver toxicity caused by sub-chronic administration of rifampicin, isoniazid and pyrazinamide in combination. Hum Exp Toxicol 2006;25:111-8

23. Nirwane AM, Bapat AR. Effect of methanolic extract of Piper nigrum fruit in ethanhol-CCl4induced hepatotoxicity in wistar rats. Pharm Lett 2012:4:795-802.

24. Bai X, Zhang W, Chen W, Zong W, Guo Z, Liu X. Anti-hepatotoxic and antioxidant effects of extracts from Piper nigrum L. root. Afr J Biotechnol 2011:10:267-72.

25. Bhavsar SK, Joshi P, Shah MB, Santani DD. Investigation into hepatoprotective activity of Citrus limon. J Pharm Biol 2007:45:303-11.

26. Saxena AK, Singh B, Anand KK. Hepatoprotective effects of Eclipta alba on subcellular levels in rats. J Ethnopharmacol 1993;40:156-61.

27. Thirumalai T, David E, Therasa SV, Elumalai EK. Restorative effect of Eclipta alba in $\mathrm{CCl}_{4}$ induced hepatotoxicity in male albino rats. Asian Pac J Trop Dis 2011;1:304-7.

28. Malloy HT, Evelyn KA. The determination of bilirubin with the photometric colorimeter, J Biol Chem, 1937;119:481-90.

29. Singal AK, Anand BS. Recent trends in the epidemiology of alcoholic liver disease. Clin Liver Dis 2013;2:53-6.

30. Leo MA, Arai M. Hepatotoxicity of vitamin A and ethanol in the rat. Gastroenterology 1982:82:194-205.

31. Tilg H, Moschen AR, Kaneider NC. Pathways of liver injury in alcoholic liver disease. J Hepatol 2011;55:1159-61.

32. Hoyt LR, Randall MJ, Ather JL, DePuccio DP, Landry CC, Qian X, et al. Mitochondrial ROS induced by chronic ethanol exposure promote hyperactivation of the NLRP3 inflammasome. Redox Biol 2017;12:883-96.

33. Zhou Z, Wang L, Song Z, Lambert JC, McClain CJ, Kang YJ. A critical involvement of oxidative stress in acute alcohol-induced hepatic TNFalpha production. Am J Pathol 2003;163:1137-46.

34. Thurman RG. Alcoholic liver injury involves activation of Kupffer cells by endotoxin. Am J Physiol 1998;275:605-11.

35. Tsukamoto H, Takei Y, McClain CJ, Shimizu H, Sato N, Thurman R. How is the liver primed or sensitized for alcoholic liver disease. Alcohol Clin Express Res 2001;25:171-81.

36. Dabba MH, Abdel-Rahman MS. Hepatoprotective activity of thymoquinone in isolated rat hepatocytes. Toxicol Lett 1998;95:23-9.

37. Jaiswal SK, Gupta VK, Siddiqi NJ, Pandey RS, Sharma B. Hepatoprotective effect of Citrus limon fruit extract against carbofuran induced toxicity in wistar rats. Chinese J Biol 2015;13:1-11.

38. Vijayakumar RS, Surya D, Nalini N. Antioxidant efficacy of black pepper (Piper nigrum L.) andpiperine in rats with high fat diet induced oxidative stress. Redox Rep 2004;9:105-10.

39. Selvendiran K, Sakthisekaran D. Chemopreventive effect of piperine on modulating lipid peroxidation and membrane bound enzymes in benzo (a) pyrene induced lung carcinogenesis. Biomed Pharmacother 2004;58:264-7

40. Juang LJ, Sheu SJ, Lin TC. Determination of hydrolyzable tannins in the fruit of Terminalia chebula Retz. by high-performance liquid chromatography and capillary electrophoresis. J Sep Sci 2004;27:718-24.

41. Panunto W, Jaijoy K, Lerdvuthisopon N, Lertprasertsuke N, Jiruntanat N, Soonthornchareonnon N, et al. Acute and chronic toxicity studies of the water extract from dried fruits of Terminalia chebula Rezt. in rats. Int J Appl Res Nat Prod 2010;3:36-43.

42. Pfundstein B, El Desouky SK, Hull WE, Haubner R, Erben G, Owen RW. Polyphenolic compounds in the fruits of Egyptian medicinal plants (Terminalia bellerica, Terminalia chebula and 
Terminalia horrida): Characterization, quantitation and determination of antioxidant capacities. Phytochemistry 2010;71:1132-48.

43. Lee HS, Jung SH, Yun BS, Lee KW. Isolation of chebulic acid from Terminalia chebula Retz. and its antioxidant effect in isolated rat hepatocytes. Arch Toxicol 2007;81:211-8.

44. Lee SI, Hyun PM, Kim SH, Kim KS, Lee SK, Kim BS, et al.
Suppression of the onset and progression of collagen induced arthritis by chebulagic acid screened from a natural product library. Arthritis Rheum 2005;52:345-53.

45. Wagner H, Geyer B, Kiso Y, Hikino H, Rao GS. Coumestans as the main active principles of the liver drugs Eclipta alba and Wedelia calendulacea. Planta Med 1986;5:370-4. 